\title{
SOCIOLOGY AND CHARITY: THE 1899 LECTURES ${ }^{1}$
}

Charles A. Ellwood

University of Nebraska

Mid-American Review of Sociology, 1988, Vol XIII, No. 2:21-30

\section{CHARITY ORGANIZATION}

In no way has the Nineteenth century been more remarkable than in the marvelous rise of humanitarian sentiment which it has witnessed. Never before has society made such strenuous efforts to aid its weaker members in the struggle for existence as it is now making. This humanitarian sentiment manifests itself not only in the founding of benevolent institutions, but especially in the organizing of practical effort to lift the lowest in society to the level of the highest. The endeavor of our modern Christian civilization, in a word, is to level up society.

This is the spirit which gave birth to the charity organization society, and it is only in the light of this spirit that charity organization as a movement, can be understood. Like the social settlement it aims to extend the principle of brotherliness or neighborliness. It aims to bring rich and poor into contact, not for the purpose of alms giving, but in order that the social efficiency of both may be increased. Charity organization then, does not mean an "arrangement for the distribution of alms," but "concerted action in neighborly service." It sees in every case of distress necessity for more than mere material aid, and inasmuch as it lays emphasis on the social efficiency of both rich and poor it emphasizes immaterial aid even more than material assistance.

The charity organization society thus seeks to treat every case of distress scientifically; that is, so thoroughly that the relief given will not be of a mere temporary character, but will effect a permanent cure. Its aim is to bring about self support through the use of wise measures of relief, coupled with personal influence and friendliness. What the physician is to the sick the charity organization society seeks to be so to the poor, only the problem fồ the chärity worker is largely one of character, and never merely one of securing physical comfort. If this be true, that character is the first thing to be considered in all charity work, it follows that "intelligent giving and intelligent withholding are alike true charity."

Intelligent methods are then the first essential in all good charity work, and it is for this perception that the charity organization society stands first of all. People have gotten tired of giving without seeing their money accomplish the good that they designed it should.

The charity organization society attempts to guarantee that energy and money in charity work are not misapplied, but that they accomplish the most good and help the most deserving. It stands for expert, educated opinion and intelligent action as against uneducated opinion and unintelligent action in charity. 
Charity organization stands secondly for co-operation in charitable work. It attempts to see that there is no overlapping in relief giving. By organizing and systematizing the philanthropic work of a city it believes that it can make it more efficient. It seeks to encourage every legitimate form of charity; it only insists that cordial co-operation and a common acceptance of scientific methods are necessary if benevolence is to attain its true end of improving social conditions.

Charity organization means, therefore, the uniting of all the philanthropic agencies of a city in a common effort to improve the condition of the poor. The work of the charity organization society, hence should be largely supervisory, and its office should be a "clearing house" for all the philanthropic work done by churches, charitable institutions, benevolent societies and individuals throughout the city.

Just as a physician is not a drug store, so the charity organization society is not a relief society. The charity organization society attempts only to diagnose each case and to prescribe in each case what should be done Actual relief can be much better administered by some other agency, not only because such other agencies exist, and the charity organization society has no right to supplant them, only to increase their efficiency, but also because the giving of material relief is apt to obscure the underlying principle of the society, which is "concerted action in neighborly service." Only "emergency relief" is therefore given by the charity organization society, and the amount of that is but a trifle compared to the amount which it uses to meet its administrative expenses.

The charity organization society is further not a society for protection against beggars and impostors. This seems to be a very common conception of its work, but it is an utterly mistaken conception. It is true that the society in its work tries to stop begging and to prevent imposition, and often employs strenuous measures to that end, but is does so as the friend of the poor and unfortunate, not as the protector of the rich. The work of detecting frauds, preventing imposition and stopping vagrancy is therefore wholly incidental to the main work of the society, not its principal object. The charity organization society would not in any way stay the flow of çharity ör "check betrevotence; on ther eortrary, it would in every way promote it, only it would direct charity into proper channels and see that is it wisely administered.

The working principles of charity organization are four -- investigation, registration, cooperation and friendly visiting. Investigation, the first principle, is much misunderstood. It is not at all for the sake of detecting imposition, and not merely to decide who are the worthy and who the unworthy. Like the diagnosis of the physician the investigation which scientific charity undertakes is made for the purpose of finding out how the case may best be helped. Just as the physician cannot know how to treat any case until he has learned all about its history, so the charity worker cannot know how to deal successfully with any case of distress until he has learned all the facts in the case. Investigation, in a word, looks toward the future rather than toward the past. Its purpose is to find out whether and in what way help can be given, not temporary help, but permanent help. "Worthy and unworthy" are not scientific categories in charity work. The question always is, can any plan to enable the applicant to work out his own regeneration be formulated? And this is the question which investigation by a diagnosis of the real needs of the case attempts to answer. Pending investigation, temporary relief should nearly always be given, so that there will be no danger of actual suffering.

The second principle of charity organization, viz., registration, is like the principle of investigation: often misinterpreted. Its purpose is not to provide a record which shall stand against the applicant for all future time. Its purpose is rather to provide a means through which the facts of the case shall be accessible to all those interested in helping the case. The registration is for the sake of helping the applicant in all cases. Without it efficient cooperation between charitable individuals and institutions would be impossible. This brings us to the third principle of charity organization work, viz., cooperation: The number of the needy who receive relief from more than one source is always very great. Not infrequently a needy family will be receiving relief from a dozen individuals, two or three churches and several benevolent societies all at the same time. The necessity of a supervisory agency to unite philanthropic effects in such cases is manifest. But it is hardly less necessary in other cases, for you can never be free from the danger of overlapping and systematized work is always more efficient than unsystematized.

The fourth principle of charity organization work is friendly visiting. Personal service is the life of all true charity. Material aid is never in any case sufficient to relieve a case of distress. In many cases immaterial aid is needed more than material relief. The charity organization society tries to touch and uplift the lives of the poor through a body of trained friendly visitors. These seek to come into relations of friendly intimacy with all who are in need. Very often it is found that their friendly counsel and advice are all that a distressed family really needs. Through the influence of personality the friendly visitor must touch the springs of character, through which alone moral regeneration can be accomplished. Friendly visiting, too, bridges the gulf between the well to do and the poor and makes-for more neighborly relations between. It especially typifies that "concerted action in neighborly service" which charity organization was defined to be.

Someone has said that if he had $\$ 600$ a year to give to the poor he would (not?) buy with it hot coal and provisions, but a man, and bind him over body and soul to be the servant of the needy. The man would probably secure more than $\$ 600$ worth of material aid, and, in addition, he would be a personal friend, an advocate, who would secure for the poor the minds and hearts, knowledge and energy of many men and women. This illustration aptly expresses the spirit of the whole charity organization movement If it uses its funds strictly for administrative expenses, not for furnishing material relief, yet it uses them to furnish personal interest, intelligence and influence, which will in the end accomplish far more for the poor than mere provisions and coal could do. 
The success of the charity organization movement in the United States has been marvelous. The charity organization society of New York, during the year ended June, 1898 , expended $\$ 50,748.30$. All of this was used for the year ended June, 1898, expended $\$ 50,748.30$. All of this "administrative purposes," not one cent was used for relief. The charity organization society of Boston cost $\$ 20,727.29$ during the year ended

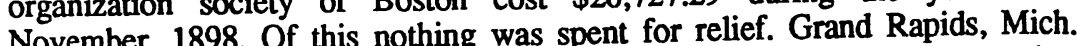
November, 1898. Of this nothing was spents) a city of nearly the same size as Lincoln (70,000 inhabitants) raised $\$ 2,972.70$ for its charity organization society during the year ended May, 1898. All of which was used to meet the administrative expenses of the society.

\section{THE RIGHT WAY TO GIVE}

There can be no right giving without love. Charity organization stands emphatically for the perception that a gift to the poor which is not backed up by personal interest and sympathy is apt to do more harm than good. The essence of charity lies in the motive, and unless love, sympathy, The essence of charity lies in the motive, and the best gifts will only demoralize the poor. Charity cannot be put upon a "business basis," if by do put charity on such a basis would be to predestine it to utter failure, to render it utterly inefficient in reaching and helping the human lives which it seeks to lift up and to save. There There can be sion of human sympathy and tenderness toward the unfortunate and the weak. The charity organization movement cordially recognizes and emphasizes the truth; only it hastens to add that the sympathy and personal interest must be constant and genuine, not spasmodic and superficial, in order to be effective.

But even after the motive of the giver is right, there are still ways and ways of giving some of which will inevitably demoralize, no matter how ways of giving, so the others have been proved to be good the motive of the giver may be, while others have been proved to be of regenerative power. Intelligent methods in giving relief are not less necessary than the right motives. The thirty years of experience which cece movement charity organization workers have had since the starting of the movement has furnished them with accurate knowledge of right methods in the giving of relief. So well, indeed, have these methods or principles of relief been worked out that a recent writer on philanthropy has said that "the principles of scientific charity are now as clearly understood and as well established as the laws of mechanics." Some of these principles of right giving this lecture will endeavor to set forth.

The first principle to be observed in the giving of relief is that relief must be so given as to strengthen, not weaken, family ties. The foundation of all social health and welfare is a sweet and wholesome family life. The disregard of family ties, of the natural obligations of children to parents, of disregard of husbands to wives, of brothers and sisters, to each other, is one of the most prolific causes of distress with which the American charity worker has to deal. It is a more frequent cause of distress than intemperance or licentious ness; while at the same time it must be recognized as a grave natural peril which threatens to disintegrate our very life as a nation. One of the chief functions of the charity organization society, therefore, is to get delinquent members of family groups to recognize and discharge their duties toward unfortunate members of their family.

Acting upon this principle in practice the charity organization society discourages the giving of relief where a husband, father, son, daughter, sister or brother is able to give the needed assistance. It emphasizes that the community has no right to weaken by unwise giving family ties which are already held too little sacred. Positively, the charity organization society by means of numerous interviews, letters, etc., endeavors to build up and strengthen family ties by getting relatives, especially children, to contribute to the support of aged or infirm members of their family. The society has been very successful in this work and counts it one of the chief phases of its social service.

In general it may be said that the principle of right giving that we have just discussed is but part of a larger principle, viz., that relief should always come from the most natural sources. The most natural and therefore the first source of relief is members of the family and relatives; the next source of relief is friends and neighbors, including former employers; the next source is the church to which the needy family belongs or some fraternal society with which it has been connected; than come special relief societies: and last of all the general public and county or city authorities. The charity organization society seeks to observe this order in securing relief for any particular needy family.

The third principle of right giving is, give only after you have a well formed plan in your mind for restoring the family to its proper place in society. Giving without a plan is like indiscriminate dosing in medicine; it will never accomplish a cure. When you give with a comprehensive plan in mind you will avoid the danger of giving for the sake of mere temporary relief; your giving will all have reference to the end of permanent welfare. Relief given without plan or purpose will soon demoralize the worthiest recipient; while by giving with some plan of regeneration in mind the hardest cases can often be dealt with successfully. The plan must of course be based upon actual facts, actual knowledge of the family's life, or else it will be worthless.

The fourth principle to be observed in the giving of relief is that relief must be adequate. This follows directly from the last principle. If a plan is formed for helping a family to become self-supporting the giving must be adequate to carry out the plan fully. Give adequately, therefore, or not at all. Nothing is so demoralizing to the poor as the giving of doles or pittances which alleviate suffering for a moment, but leave them wholly in uncertainty as regards the future. It is far better to give to a few and give adequately than to give to many and help none permanently. It is really an unkind act to give a small amount to a person asking relief and follow it up by no efforts to secure permanent welfare. What has been said under 
these two headings, however, must not be construed to mean that temporary aid, if necessary to prevent actual suffering, should not be given pending investigation of the case and the forming of a plan to bring about self support.

The fifth principle to be observed in the giving of relief is that relief should be private and given in the home of the recipient. "It is of the very essence of charity that it should be private." Free soup kitchens and free public dinners for the poor are in the long run demoralizing. So, too, giving to strangers who ask for food, etc. in one's back yard. Relief should be given in the homes of the recipients or not at all. This principle has two important concrete applications, viz., to tramps and begging children.

It is doubtless through the unwise charity which prompts the feeding of strangers at one's back door that the tramp case is created. Strangers thus asking for relief should always be sent to some central agency like the charity organization society who can properly investigate their case and give adequate assistance. Nothing can do more harm than to give to begging children. They should be either accompanied to their homes or persuaded to give the names and addresses of their parents. The former, though the more difficult, is the better method. As a rule self-respecting parents do not send out their children to beg, and by giving to them we are encouraging the worst forms of vice and crime. It is a safe rule that nothing, not even food, should be given at the back door to children and tramps.

The sixth principle of right giving is give with reference to the welfare of the community rather than with reference simply to the welfare of an individual family. It is wrong to give to one family so lavishly that we excite false hopes and envyings among its neighbors or in the social class to which it belongs. This often happens when, through some misfortune, the needs of a destitute family get advertised in the newspapers, and a whole car load of relief comes tumbling in upon them. No greater misfortune can happen to a poor family than this.

The seventh principle of right giving is never give relief when by your giving you know that you will encourage the recipient in some wrong or vicious course of life, or in others words make your giving conditional upon a certain course of conduct." This -is perhaps a very hard principle to observe. But we must make the poor our partner in our efforts to improve their condition. Especially is this the case when some vicious habit is the cause of the distress. It is only by making them our partners in our effort to work out this regeneration that we can succeed at all. Our giving in families where there is intemperance, shiftlessness, or any wrong ways of living must be conditional upon the following of a certain line of conduct. This does not mean that we should not give to such families at all, but only in proportion as they show a disposition to mend their ways. We must make them understand that we have made them partners with us in working out this social salvation, and that we are willing to help them in proportion as they will make it possible for us to help them.

These seven principles to be observed in the giving of relief can perhaps be summed up in a single principle, viz.,: Give under the super- vision and through some central agency which is able to carry out these principles. It is evident from inspecting the principles of right giving that it is seldom that a single individual can carry them out unaided, unless intelligence, great wealth, and an abundance of leisure be his. As principles in relieving the poor they are, however, established beyond question. They are not impractical; they simply need a central agency which will furnish expert supervision to put them into operation. Such an agency the charity organization society tries to be. For thirty years it has successfully applied these principles in relieving the poor, with the result that in the cities where charity organization has been rightly tried it has reduced pauperism 40 and even as high as 73 per cent.

Some inquiries have been raised with regard to the statement in the last lecture that all the funds of the charity organization society are used for administrative purposes, and not for relief. It may be right to state here that the charity organization society secures relief for each case individually from the proper sources, but it seeks to organize the sources of relief rather than to be a relief society. If there is no other way of relief it raises money for each case individually. But there are already in Lincoln over sixty relief societies, so that the charity organization society has no need to act as a relief society directly. By so doing it would only arouse the jealousy and animosity of the relief societies, and would at the same time abdicate its high function of acting as a supervisory agency to secure relief for poor which is in accordance with accepted scientific principles. Besides the charity organization society has difficulty in raising the modest sum necessary to meet its administrative expenses, to say nothing of using a part of its funds for relief.

\section{OUR GREATEST DUTY IS TO THE POOR}

The socialists tell us that charity only aggravates social evils -- that it may be likened to the dropping of water upon a redhot griddle, the only result to make it sizzle. If by charity is meant the mere giving of alms, I can heartily agree with them; but not if the word be used in the larger and truer sense. The socialists say; "Not charity but justice". -- not charity in the sense of alms-giving, but social justice. If our charity be broad enough and our justice sufficiently far-reaching, there is here no contradiction in terms. We must look at the question of helping the poor from the point of view of justice. Our greatest duty to the poor is the obtaining for them of social justice.

The socialists would overtum existing institutions and give equally of the goods of the earth to every man. True justice to the poor implies, first, equality of opportunity; and second, compensation for service or injury. We must obtain for the poor equal opportunities for self-help. All material aid given should look toward the self support of the recipient. In the spiritual realm, Christians are looking to the eternal, not the temporary welfare of mankind.

Among the practical facilities for self-help which it is the aim of the 
charity organization societies to provide may be mentioned, first, the loan fund, from which the poor may be given small amounts to tide them over periods of distress, of sickness, of financial crisis, and from which loans may be made to start men in business.

In this connection I do not care to discuss the question if interest be ethical. A large class of socialists, and they are upheld by many Christian men and women, maintain that the taking of interest is in all cases unethimen and women, maintain that the taking of intere charged to the poor. In this connection, the taking of interest is unbrotherly, essentially immoral. It may be said that if a man's character be good, loans can be obtained without resorting to a charity organization society. This may be true in the country or in small towns, where everybody is known to everybody else; but it is not true in the large cities, where one must go to the pawnbrokers' shops and pay all the way from 20 to 150 per cent interest. In the operation of the loan fund, a sharp distinction must be drawn between loan and gift; and there must be good probability of repayment in order that loans may be made. The loan fund is one of the greatest helps to the poor.

The second facility for self-help which we shall consider is employment. The charity organization society here has for some time tried to act in the capacity of an employment bureau. How helpful the society shall be in this capacity depends upon your co-operation, upon how much you will use it. When work in private families cannot be obtained for the poor, work should be provided by the establishment of wood yards and the. like. The man who has for some time been conducting a wood yard in your community for the unemployed has been accomplishing as much for charity as any one the tramp desires to become self-supporting; and by means of it, you are enabled to keep him longer under your observation and influence. A work test of a man's genuineness coupled with true interest in him, is one of the most effective means for his regeneration.

Third among facilities for self help I would consider facilities for systematic saving. The national postage savings bank, established in Great Britain and Germany, where sums to the extent of -5 and 10 cents can be deposited, have proven of greatest value in the amelioration of poverty. In many cities in our country has been established the penny provident savings system for children. The children buy stamps for from 1 cent upward and paste them in a book. When the book is full, the stamps are redeemed. This system can, and I hope will be, carried out in Lincoln. A member of the board of the charity organization society said to me the other day, "Our goard of duty to the poor is to teach them to work." It is one of our greatest duties to the poor. The establishment of facilities for self-help should not be neglected by any community. In this connection I would advise the adoption of manual training in our schools and out of them -- manual training, not of the superficial and foolish kind which has been advocated sometimes, but manual training which does really train boys and girls and fit them for self support. We should have free industrial schools where the poor can go directly from the common schools. Here in Lincoln some of the churches have maintained sewing and cooking schools. Lack of knowledge on the part of the poor of ways to help themselves, to wisely conduct their households, is one of the crying social needs.

The charity organization society aims to encourage in every way every such effort as the trade schools. In the absence of manual training in the public schools, the society seeks to act through its friendly visitors in giving instruction in sewing, cooking and the like, enabling families to learn to live decently and wholesomely. Through the friendly visitors we reach the adults as well and the children. Through these is greater hope of helping the children, we must not despair of the adults. Tact combined with true sympathy will accomplish much.

The second requirement of social justice is compensation. As one of the first methods under this head I would name old age pensions, not governmental, as socialists demand, but out of the voluntary giving of the well-todo in the community. It is just that the aged man, or woman who has done well his or her part in life, who has lived worthily and if left without friends or family, should be pensioned. No worthy life should ever be ended in the poorhouse. Every charity organization society believes this. We hope some day to obtain old age pensions for the worthy. The question we must ask in according these pensions is, have they lived worthily, in such a way as to help humanity?

Another agent for the obtaining of social justice is a bureau of justice where legal justice can be obtained for the poor free of cost. This is one of the great hobbies of Herbert Spencer, who asks: "Why not give free justice?" There ought to be in any town of any considerable size a bureau of justice. In conducting such a bureau much discretion and wisdom must be used. Two important factors in obtaining justice for the poor are good government and neighborliness. The poor are the chief sufferers under a rotten municipal government. The districts where they live go unpaved, sanitation is neglected, and they suffer in many ways unknown to the more favored class. The class exclusiveness which is growing up in our land is a threatening evil. It must be abolished, neighborliness must be established, if we would have social justice. Neighborliness is our greatest duty to the poor. The charity organization society aims to establish neighborliness in our relations with Lincoln's poor.

\section{EDITORIAL NOTE BY MICHAEL R. HILL}

1. The three, generally unavailable lectures reprinted here were addressed initially to the members of the Charity Organization Society in Lincoln, Nebraska. The lectures were then published in a local newspaper, the Nebraska State Journal, in 1899 on October 29 , November 11 , and November 20 , respectively. Three additional lectures were scheduled for presentation in 1900.

Ellwood's lectures are historically unique. They are the first formal, public presentations in Lincoln by the first instructional 
Mid-American Review of Sociology

officer of the University of Nebraska to hold appointment specifically as a sociologist. More generally, the lectures illustrate the fusion of moralist and scientific themes in the Christian sociology typified by Ellwood (for further discussion of this latter point, see Ball's paper on "Howard's Institutional Sociology of Marriage and Family," elsewhere in this issue).

In 1899, Charles A. Ellwood completed his doctorate on "Some Prolegomena to Social Psychology" at the University of Chicago and accepted simultaneous appointments as Secretary of the Charity Organization Society of Lincoln, Nebraska, and as Lecturer (later, Instructor) in sociology at the University of Nebraska. During the year 1899-1900, Ellwood offered several sociology courses, for which he was not paid, as George E. Howard recounts -- elsewhere in this issue -- in his "History of Sociology in the University of Nebraska." Subsequently, Ellwood accepted an offer to become Professor of Sociology (with pay) at the University of Missouri.

For documentation of Ellwood's accomplishments, see Harry Elmer Barnes' two accounts. Specifically, "Charles Abram Ellwood Founder of Scientific Psychological Sociology," in Barnes' Intro duction to the History of Sociology, 1948, pp. 853-68; and Barnes' essay on Ellwood in the International Encyclopedia of the Social Sciences, vol. 5, 1968, pp. 31-33. Curiously, Barnes omits mention of Ellwood's first academic appointment and year in Nebraska in the latter article.

\section{THE STRANGER AT THE CURB}

\section{Mari Sandoz}

Lincoln, Nebraska

Mid-American Review of Sociology, 1988, Vol. XIII, No. 2:31-41

The velvet purr of the engine became even softer. The strange young man looked hopefully over his smart roadster at me, gave the slightest, most inconspicuous nod ahead. My hand moved vertically, a bare inch. The purr became a roar.

Once more, for the sixth time in as many blocks, Romance was repulsed. Or perhaps I only saved my arches.

And the parade of beckoning strangers at the curb is growing. Ten years ago it took some slight encouragement to get an offer of a pick-up on the sedate streets of Lincoln, Nebraska. Today it requires considerable sales resistance to slick cars and well-dressed soft-spoken young men to get home without taking at least one flier. ${ }^{2}$ Nor need you be a dewy-eyed Ziegfelder. A frank thirtiness not particularly redeemed by an under-fed, 'teenish body and a pinch of swank with your clothes will do. Not even a stack of omnibus volumes on your arm will discourage these avid companion seekers, ${ }^{3}$ by no means restricted to local talent. Among the 385 cars whose license plates I scrutinized during the last year were representatives from every state of the Union and three provinces of Canada.

I was not ready to accept the verdict of depravity passed upon the curber by the church and social workers and the good women of my acquaintance. Particularly when, on a Sunday evening stroll along the six blocks home from the city library with a ragged note book. under my arm, the curb seemed literally lined, every intersection blocked by hopefuls, I began to wonder. Who are these knights of the pavements and, as your great grandfather asked of your grandmother's boy friends, what are their intentions?

Why not interview them? I would at least get their "line" that way. I purchased a tiny blue notebook with an inch of pencil attached, pulled on my ône dress with" any air at all, lớoked" tó my lipstick, rehearsed a few questions and a pose or two before my slightly distorting mirror and took to the streets.

Copyright 1989 Mari Sandoz Estate

All Rights Reserved 